\title{
SUBSTITUSI INULIN UMBI GEMBILI (DIOSCOREA ESCULENTA) PADA PRODUK ES KRIM SEBAGAI ALTERNATIF PRODUK MAKANAN TINGGI SERAT DAN RENDAH LEMAK
}

\author{
Fanny Karina Dewanti, Arintina Rahayuni*) \\ Program Studi Ilmu Gizi Fakultas Kedokteran Universitas Diponegoro \\ Jl.Dr.Sutomo No.18, Semarang, Telp (024) 8453708, Email : gizifk@ undip.ac.id
}

\begin{abstract}
Background: Ice cream is a food product containing high energy. Inulin can be used as low fat component product. It contains high fiber and act as functional food. Inulin can be found in high amount in tuber. This study will be done to know about the substitution of inulin from gembili in ice cream product.

Objective: To analyze fiber, fat, physic quality (melting rate and overrun), and acceptable intake of ice cream with substitution of inulin from gembili.

Method: This experimental study using one factor randomized design, that is inulin concentration of gembili $(2 \%$, $3 \%$, and 4\%). It analyzed crude fiber contain, fat, physic quality (melting rate and overrun), and acceptable intake of ice cream. Fiber contain and fat were examined using one way ANOVA and LSD (Least Significance Different) test. Physic quality data were described with counting mean of melting rate and overrun. Acceptable intake was done by hedonic test, then it was analyzed using Friedman test and Wilcoxon with degree of confidence of $95 \%$.

Result: The substitution of inulin from gembili had effect to increase fiber and decrease fat contain in ice cream. Ice cream containing $4 \%$ of substitution inulin from gembili was the most resistant toward melting process. Ice cream with substitution inulin from gembili had low overrun. The substitution of inulin from gembili affected the decreasing acceptance intake level of ice cream.

Conclusion: $4 \%$ of substitution inulin from gembili of ice cream contained the highest fiber and the lowest fat. Recommended product was ice cream with $2 \%$ of substitution inulin from gembili.

Keywords : fiber; fat; ice cream; inulin; gembili
\end{abstract}

\begin{abstract}
ABSTRAK
Latar Belakang: Es krim merupakan produk makanan tinggi energi. Inulin banyak digunakan sebagai komponen produk rendah lemak. Inulin memiliki kandungan serat yang tinggi dan termasuk pangan fungsional. Umbi diketahui memiliki kandungan inulin cukup tinggi. Oleh karena itu, akan dilakukan penelitian mengenai substitusi inulin umbi gembili pada produk es krim.

Tujuan: Menganalisis perbedaan kadar serat, lemak, kualitas fisik meliputi melting rate dan overrun, serta tingkat penerimaan es krim dengan substitusi inulin umbi gembili.

Metode: Merupakan penelitian eksperimental dengan rancangan acak lengkap satu faktor yaitu konsentrasi inulin umbi gembili (2\%, 3\%, dan 4\%). Analisis yang dilakukan adalah kadar serat kasar, lemak, sifat fisik (melting rate dan overrun), dan tingkat penerimaan es krim. Kadar serat dan lemak diuji menggunakan one way Anova dilanjutkan uji LSD (Least Significance Different). Data sifat fisik es krim dideskripsikan dengan menghitung rerata melting rate dan overrun. Tingkat penerimaan dilakukan dengan uji hedonik kemudian dianalisis dengan uji Friedman dilanjutkan uji Wilcoxon pada derajat kepercayaan $95 \%$.

Hasil: Substitusi inulin umbi gembili berpengaruh terhadap peningkatan kadar serat dan penurunan kadar lemak es krim. Es krim dengan substitusi inulin umbi gembili $4 \%$ paling tahan terhadap pelelehan. Es krim dengan substitusi inulin umbi gembili memiliki overrun yang rendah. Substitusi inulin umbi gembili berpengaruh terhadap penurunan tingkat penerimaan es krim.
\end{abstract}

Simpulan: Kadar serat paling tinggi dan kadar lemak paling rendah adalah es krim dengan substitusi inulin umbi gembili 4\%. Es krim yang direkomendasikan adalah es krim dengan substitusi inulin umbi gembili $2 \%$.

Kata Kunci : serat; lemak; es krim; inulin; gembili

\section{PENDAHULUAN}

Obesitas dikaitkan dengan beberapa resiko penyakit seperti hiperlipidemia, hipertensi, cardiovaskuler, diabetes, kanker dan kematian. ${ }^{1,2,3}$ Menurut National Health and Nutrition Examination Survey (NHANES) prevalensi obesitas tahun 2007-2008 yaitu sebesar 33,8\% dan diperkirakan akan meningkat sekitar 33\% pada tahun 2030. ${ }^{4}$ Berdasarkan Riset Kesehatan Dasar (Riskesdas) tahun 2010, prevalensi obesitas pada anak usia sekolah (6-12 tahun) yaitu sebesar 9,2\%. Prevalensi obesitas pada anak laki-laki yaitu $10,7 \%$ sedangkan pada anak perempuan yaitu $7,7 \%$. Prevalensi obesitas pada anak usia diatas 15 tahun mencapai $19,1 \%$, sedangkan pada remaja usia $16-$ 18 tahun yaitu $1,4 \%$. Prevalensi obesitas lebih 
tinggi pada remaja perempuan dibanding remaja laki-laki yaitu $1,5 \%$ dan $1,3 \% .^{5}$

Kebiasaan konsumsi makanan yang tinggi energi menjadi salah satu faktor penyebab obesitas. Es krim merupakan salah satu produk makanan yang tinggi energi, hal ini terjadi karena bahan baku utama pembuatan es krim adalah susu. ${ }^{6}$ Kandungan gizi dalam $100 \mathrm{~g}$ es krim yaitu 210 kkal energi, $4 \mathrm{~g}$ protein, 12,5 g lemak, 20,6 g karbohidrat. $^{7}$ Konsumsi es krim di Indonesia diketahui pada tahun 2009 mencapai 0,15 liter per kapita. $^{8}$

Kualitas es krim tidak hanya dinilai dari cita rasanya yang enak, tetapi juga dinilai dari segi tekstur. Kandungan lemak dan gula dapat memperbaiki tekstur es krim sehingga akan dihasilkan tekstur yang creamy dan melty saat berada di mulut sehingga banyak disukai. Kandungan lemak yang tinggi yaitu sekitar 8-20\% dan gula 13-20\% merupakan sumber energi terbesar pada es krim. Pengurangan lemak pada es krim low fat dapat mempengaruhi kualitas es krim salah satunya yaitu tekstur yang dihasilkan.

Inulin banyak digunakan secara luas di industri pangan yaitu sebagai salah satu komponen produk-produk rendah lemak. Inulin termasuk karbohidrat dengan panjang rantai 2-60 unit. Inulin rantai panjang (22-60 unit) bersifat kurang larut dan lebih kental sehingga dapat digunakan sebagai pengganti lemak. ${ }^{9}$ Daya ikatnya terhadap air dapat membantu memodifikasi tekstur pada es krim. Inulin membentuk mikrokristal apabila dilarutkan dengan air atau susu. Mikrokristal ini tidak dapat dirasakan mulut, tetapi dapat mempengaruhi pembentukan tekstur yang halus dan creamy, serta terasa seperti lemak saat dikunyah di mulut. ${ }^{10}$ Inulin merupakan salah satu komponen bahan pangan yang banyak dimanfaatkan sebagai pangan fungsional karena memiliki kandungan serat yang tinggi. Inulin bersifat prebiotik dimana inulin tidak dapat dicerna oleh enzim-enzim pencernaan, tetapi di dalam usus besar inulin akan terfermentasi oleh bakteri bifidobacterium yang banyak memberikan manfaat kesehatan pada tubuh. ${ }^{11}$ Inulin sering digunakan dalam bidang medis dan farmasi karena dapat mengurangi resiko kanker usus besar dan menormalkan kadar gula darah pada penderita diabetes. $^{12}$ Inulin diketahui dapat membantu memetabolisme lemak sehingga mempengaruhi penurunan kolesterol dan trigliserida. ${ }^{13}$

Inulin yang diproduksi secara komersial biasanya berasal dari jerusalem artichoke (Helianthys tuberosus) dan chicory (Cichorium intybus), tetapi tanaman tersebut tidak banyak ditemukan di Indonesia. Tanaman yang banyak ditemukan dan tumbuh di Indonesia salah satunya adalah umbi (Dioscorea spp). Umbi termasuk pangan lokal yang tidak hanya digunakan sebagai sumber pangan alternatif, tetapi diketahui memiliki kandungan inulin yang cukup tinggi. Inulin yang digunakan dalam penelitian ini berasal dari umbi jenis Dioscorea esculenta atau gembili yang menurut penelitian merupakan umbi yang memiliki kandungan inulin dan serat tertinggi yaitu sebesar $14,629 \%$ (bk) dan $6,386 \% .^{14}$

Berdasarkan hal tersebut, akan dilakukan penelitian mengenai peningkatan serat pada es krim rendah lemak yang dilakukan dengan cara mensubstitusi sumber lemak pada es krim menggunakan inulin yang berasal dari ekstraksi umbi gembili.

\section{METODE}

Penelitian yang dilakukan termasuk dalam bidang Produksi Makanan atau Food Production. Penelitian ini dilaksanakan mulai bulan Juni hingga Juli 2013 di Laboratorium Ilmu Teknologi Pangan Universitas Muhammadiyah Semarang dan Laboratorium Ilmu Teknologi Pangan Universitas Gajah Mada Yogyakarta.

Penelitian ini merupakan penelitian eksperimental dengan rancangan acak lengkap satu faktor. Terdapat 3 konsentrasi inulin umbi gembili yang berbeda pada pembuatan es krim dan terdapat 1 kontrol $(\mathrm{t}=4)$ dengan simbol $\mathrm{P}_{0}, \mathrm{P}_{1}, \mathrm{P}_{2}, \mathrm{P}_{3}$. Substitusi inulin dengan 3 konsentrasi berbeda diperoleh dari penelitian pendahuluan. Pada penelitian pendahuluan, es krim dibuat dengan substitusi inulin 1\%, 2\%, 3\%, 4\%, 5\%, $6 \%$. Berdasarkan hasil penelitian pendahuluan diketahui bahwa es krim dengan substitusi inulin $2 \%, 3 \%$, dan $4 \%$ adalah yang paling disukai panelis dengan rerata skor yaitu 3.58, 3.24, dan 3.10 yang termasuk dalam kategori suka. Es krim kontrol pada penelitian ini diperoleh dari formula standar es krim tanpa substitusi inulin umbi gembili. Setiap perlakuan dilakukan tiga kali ulangan yang dianalisis secara duplo sedangkan uji tingkat penerimaan dilakukan satu kali tanpa pengulangan.

Bahan-bahan yang digunakan dalam pembuatan es krim antara lain susu skim "IndoPrima", Wippy cream "Haan", umbi gembili yang digunakan untuk ekstraksi inulin diperoleh dari Desa Pituruh, Purworejo, Jawa Tengah, Gula pasir "Sembilan", CMC diperoleh dari toko bahan roti "Intisari", dan telur. Spesifikasi bahan-bahan yang digunakan yaitu kemasan tertutup rapat, tidak 
kadaluarsa, tidak menggumpal, dan telur tidak retak atau busuk.

Proses ekstraksi inulin umbi gembili mengacu pada metode Livingston, Farrar, and Pollock dengan prinsip pelarutan inulin dalam air pada suhu tinggi dan pengendapan dengan etanol. ${ }^{15}$ Es krim dibuat melalui proses pencampuran bahan, pasteurisasi, homogenisasi, pendinginan, penggunaan ice cream maker, dan pembekuan.

Data yang dikumpulkan meliputi kadar serat kasar, kadar lemak, sifat fisik (melting rate dan overrun), dan tingkat penerimaan es krim dengan substitusi inulin umbi gembili. Kadar serat diukur dengan metode gravimetri ${ }^{16}$, kadar lemak diukur dengan metode mojonnier ${ }^{17}$, data melting rate dihitung dengan rumus melting rate ${ }^{18}$, data overrun dihitung menggunakan rumus persen overrun ${ }^{19}$, dan tingkat penerimaan menggunakan uji hedonik meliputi warna, rasa, tekstur, dan aroma yang diuji oleh 20 orang panelis agak terlatih yaitu mahasiswa Program Studi Ilmu Gizi Universitas Diponegoro dengan 5 skala penilaian yaitu $5=$ sangat suka, $4=$ suka, $3=$ netral, $2=$ tidak suka, dan 1 = sangat tidak suka.

Pengaruh substitusi inulin umbi gembili terhadap kadar serat dan lemak diuji menggunakan one way Anova dilanjutkan uji LSD (Least Significance Different) pada derajat kepercayaan 95\%. Data melting rate dan overrun dirata-rata untuk mendeskripsikan sifat fisik es krim kemudian membandingkannya dengan standar. Data hasil uji tingkat penerimaan dianalisis dengan uji Friedman dilanjutkan uji Wilcoxon menggunakan program komputer untuk mengetahui beda nyata antar perlakuan pada derajat kepercayaan $95 \%$.

\section{HASIL}

\section{Ekstraksi Inulin Umbi Gembili (Dioscorea esculenta)}

Proses ekstraksi inulin umbi gembili menggunakan prinsip pelarutan inulin dalam air pada suhu tinggi dan pengendapan dengan etanol. ${ }^{15}$ Hasil ekstraksi umbi gembili mendapatkan inulin sebesar 10,92\% (bk).

\section{Kadar Serat Es Krim dengan Substitusi Inulin Umbi Gembili}

Hasil analisis kadar serat kasar es krim dengan substitusi inulin umbi gembili secara singkat dapat dilihat pada Tabel 1.

Tabel 1. Rerata Kadar Serat Kasar Es Krim dengan Substitusi Inulin Umbi Gembili

\begin{tabular}{cc}
\hline Jenis Perlakuan & Rerata $(\mathbf{g})$ \\
\hline Kontrol & $1.07 \pm 0.05^{\mathrm{d}}$ \\
Substitusi Inulin 2\% & $1.47 \pm 0.02^{\mathrm{c}}$ \\
Substitusi Inulin 3\% & $2.07 \pm 0.04^{\mathrm{b}}$ \\
Substitusi Inulin 4\% & $2.80 \pm 0.04^{\mathrm{a}}$ \\
\hline & $\mathrm{p}=0.000$ \\
\hline
\end{tabular}

Keterangan: Angka yang diikuti dengan huruf superscript berbeda (a, $\mathrm{b}, \mathrm{c}, \mathrm{d})$ menunjukkan beda nyata

Kadar serat kasar es krim dengan substitusi inulin umbi gembili memiliki rerata antara $1,07 \%-$ $2,80 \%$. Kadar serat tertinggi terdapat pada es krim dengan substitusi inulin umbi gembili $4 \%$, sedangkan kadar serat terendah adalah es krim kontrol. Hasil analisis kadar serat menggunakan uji one way Anova CI 95\% menunjukkan bahwa substitusi inulin umbi gembili berpengaruh nyata terhadap peningkatan kadar serat es krim. Uji lanjut menggunakan uji LSD (Least Significance
Different) menunjukkan bahwa perlakuan es krim kontrol memiliki perbedaan bermakna terhadap perlakuan es krim dengan substitusi inulin umbi gembili $2 \%, 3 \%$, dan $4 \%$.

\section{Kadar Lemak Es Krim dengan Substitusi Inulin Umbi Gembili}

Hasil analisis kadar lemak es krim dengan substitusi inulin umbi gembili secara singkat dapat dilihat pada Tabel 2 . 
Tabel 2. Rerata Kadar Lemak Es Krim dengan Substitusi Inulin Umbi Gembili

\begin{tabular}{cc}
\hline Jenis Perlakuan & Rerata (\%) \\
\hline Kontrol & $4,15 \pm 0.03^{\mathrm{a}}$ \\
Substitusi Inulin 2\% & $3,70 \pm 0.07^{\mathrm{b}}$ \\
Substitusi Inulin 3\% & $3,58 \pm 0.09^{\mathrm{b}}$ \\
Substitusi Inulin 4\% & $3,21 \pm 0,03^{\mathrm{c}}$ \\
\hline & $\mathrm{p}=0.000$ \\
\hline
\end{tabular}

Keterangan: Angka yang diikuti dengan huruf superscript berbeda (a, $b, c)$ menunjukkan beda nyata

Berdasarkan Tabel 3, kadar lemak es krim dengan substitusi inulin umbi gembili memiliki rerata antara $3,21 \%$ - 4,15\%. Kadar lemak tertinggi terdapat pada es krim kontrol, sedangkan kadar lemak terendah adalah es krim dengan substitusi inulin $4 \%$. Hasil analisis kadar lemak menggunakan uji one way Anova CI 95\% menunjukkan bahwa substitusi inulin umbi gembili berpengaruh nyata terhadap penurunan kadar lemak es krim. Uji lanjut menggunakan uji LSD (Least Significance Different) menunjukkan bahwa perlakuan es krim kontrol memiliki perbedaan bermakna terhadap perlakuan es krim dengan substitusi inulin umbi gembili $2 \%, 3 \%$, dan $4 \%$. Es krim dengan substitusi inulin umbi gembili $4 \%$ juga mempunyai perbedaan bermakna terhadap es krim substitusi inulin umbi gembili $2 \%$ dan $3 \%$.

\section{Sifat Fisik Es Krim dengan Substitusi Inulin Umbi Gembili}

Rerata melting rate es krim dengan substitusi inulin umbi gembili berkisar antara 0,44 - 0,76 $\mathrm{ml} / \mathrm{menit}$. Perlakuan es krim kontrol memiliki melting rate tertinggi. Nilai melting rate paling rendah adalah perlakuan es krim dengan substitusi inulin $4 \%$.

Rerata nilai overrun es krim dengan substitusi inulin umbi gembili berkisar antara 27,33\% $36,83 \%$. Rerata nilai overrun tertinggi adalah perlakuan es krim kontrol, sedangkan rerata nilai overrun terendah adalah es krim dengan substitusi inulin umbi gembili $4 \%$. Hasil rerata nilai melting rate dan overrun dapat dilihat pada Tabel 3.

Tabel 3. Rerata Sifat Fisik (Melting Rate dan Overrun) Es Krim dengan Substitusi Inulin Umbi Gembili

\begin{tabular}{ccc}
\hline Jenis Perlakuan & Melting Rate $(\boldsymbol{m l} /$ menit) & Overrun (\%) \\
\hline Kontrol & $0.76 \pm 0.43$ & $36.83 \pm 4.37$ \\
Substitusi Inulin 2\% & $0.69 \pm 0.27$ & $33.78 \pm 4.13$ \\
Substitusi Inulin 3\% & $0.54 \pm 0.27$ & $28.03 \pm 1.57$ \\
Substitusi Inulin 4\% & $0.44 \pm 0.27$ & $27.33 \pm 2.27$ \\
\hline
\end{tabular}

\section{Tingkat Penerimaan Es Krim dengan Substitusi Inulin Umbi Gembili \\ melaksanakan uji hedonik meliputi kesukaan \\ Data tingkat penerimaan es krim dengan substitusi inulin umbi gembili didapatkan dengan terhadap warna, rasa, tekstur, dan aroma. Hasil rerata tingkat penerimaan es krim dengan substitusi inulin umbi gembili dapat dilihat pada Tabel 4.}

Tabel 4. Rerata Tingkat Kesukaan Panelis terhadap Es Krim dengan Substitusi Inulin Umbi Gembili

\begin{tabular}{|c|c|c|c|c|c|c|c|c|}
\hline \multirow{2}{*}{ Perlakuan } & \multicolumn{2}{|c|}{ Warna } & \multicolumn{2}{|c|}{ Rasa } & \multicolumn{2}{|c|}{ Tekstur } & \multicolumn{2}{|c|}{ Aroma } \\
\hline & Rerata & Ket & Rerata & Ket & Rerata & Ket & Rerata & Ket \\
\hline Kontrol & $4.50 \pm 0.61^{\mathrm{a}}$ & Sangat & $4.15 \pm 1.08^{\mathrm{a}}$ & Suka & $4.10 \pm 0.96^{\mathrm{a}}$ & Suka & $4.05 \pm 0.95^{\mathrm{a}}$ & Suka \\
\hline Substitusi $2 \%$ & $3.50 \pm 0.68^{\mathrm{b}}$ & Suka & $4.00 \pm 0.65^{\mathrm{a}}$ & Suka & $3.90 \pm 0.78^{\mathrm{a}}$ & Suka & $3.35 \pm 0.81^{\mathrm{b}}$ & Netral \\
\hline Substitusi 3\% & $3.05 \pm 0.68^{\mathrm{c}}$ & Natrol & $3.10 \pm 0.78^{\mathrm{b}}$ & Netral & $2.85 \pm 0.87^{\mathrm{b}}$ & Netral & $3.25 \pm 0.85^{\mathrm{b}}$ & Netral \\
\hline \multirow[t]{2}{*}{ Substitusi $4 \%$} & $2.70 \pm 0.86^{\mathrm{c}}$ & $\begin{array}{l}\text { Netral } \\
\text { Netral }\end{array}$ & $2.75 \pm 1.02^{\mathrm{b}}$ & Netral & $2.90 \pm 0.91^{\mathrm{b}}$ & Netral & $2.75 \pm 0.44^{\mathrm{c}}$ & Netral \\
\hline & \multicolumn{2}{|c|}{$p=0.000$} & \multicolumn{2}{|c|}{$p=0.000$} & \multicolumn{2}{|c|}{$p=0.000$} & \multicolumn{2}{|c|}{$p=0.000$} \\
\hline
\end{tabular}

Keterangan: Angka yang diikuti dengan huruf superscript berbeda (a, b, c) menunjukkan beda nyata

Hasil tingkat penerimaan panelis terhadap parameter warna es krim dengan substitusi inulin umbi gembili memiliki rerata antara $2,70-4,50$.

Nilai rerata paling rendah adalah es krim dengan 
substitusi inulin umbi gembili $4 \%$, sedangkan nilai rerata paling tinggi adalah es krim kontrol. Hasil uji Friedman menunjukkan bahwa es krim dengan substitusi inulin umbi gembili berpengaruh nyata terhadap tingkat penerimaan warna es krim. Berdasarkan uji lanjut Wilcoxon diperoleh hasil bahwa perlakuan es krim kontrol mempunyai perbedaan bermakna terhadap perlakuan es krim dengan substitusi inulin umbi gembili $2 \%, 3 \%$, dan $4 \%$. Es krim dengan substitusi inulin umbi gembili $2 \%$ juga mempunyai perbedaan bermakna terhadap es krim substitusi inulin umbi gembili $3 \%$ dan $4 \%$.

Tingkat penerimaan rasa menunjukkan bahwa es krim dengan substitusi inulin umbi gembili $4 \%$ memiliki tingkat penerimaan terendah dengan rerata 2,75 sedangkan tingkat penerimaan tertinggi adalah es krim kontrol dengan rerata 4,15. Hasil analisis menggunakan uji Friedman menunjukkan bahwa es krim dengan substitusi inulin umbi gembili berpengaruh nyata terhadap tingkat penerimaan rasa es krim. Berdasarkan uji lanjut Wilcoxon menunjukkan bahwa perlakuan es krim kontrol berbeda secara bermakna terhadap perlakuan es krim dengan substitusi inulin umbi gembili $3 \%$ dan $4 \%$, sedangkan terhadap es krim dengan substitusi inulin umbi gembili $2 \%$ tidak ada beda. Perlakuan es krim dengan substitusi inulin umbi gembili 2\% memiliki hubungan beda bermakna terhadap es krim dengan substitusi inulin umbi gembili $3 \%$ dan $4 \%$.

Tingkat penerimaan tekstur es krim dengan substitusi inulin umbi gembili memiliki rerata antara 2,85-4,10. Nilai rerata paling rendah adalah es krim dengan substitusi inulin umbi gembili 3\%, sedangkan nilai rerata paling tinggi adalah es krim kontrol. Hasil uji Friedman menunjukkan bahwa es krim dengan substitusi inulin umbi gembili berpengaruh nyata terhadap tingkat penerimaan tekstur es krim. Uji beda Wilcoxon menunjukkan bahwa perlakuan es krim kontrol memiliki perbedaan bermakna terhadap es krim dengan substitusi inulin umbi gembili 3\% dan $4 \%$, sedangkan terhadap es krim dengan substitusi inulin umbi gembili $2 \%$ tidak ada beda. Perlakuan es krim dengan substitusi inulin umbi gembili $2 \%$ memiliki perbedaan bermakna terhadap es krim substitusi inulin umbi gembili $3 \%$ dan $4 \%$.

Tingkat penerimaan aroma es krim dengan substitusi inulin umbi gembili menunjukkan bahwa es krim kontrol merupakan es krim dengan tingkat penerimaan aroma paling tinggi dengan rerata 4,05 , sedangkan tingkat penerimaan aroma es krim terendah adalah es krim dengan substitusi inulin umbi gembili $4 \%$ dengan rerata 2,75 . Hasil analisis uji Friedman menunjukkan bahwa es krim dengan substitusi inulin umbi gembili berpengaruh nyata terhadap tingkat penerimaan aroma es krim. Hasil uji Wilcoxon menunjukkan bahwa perlakuan es krim kontrol memiliki perbedaan bermakna terhadap perlakuan es krim dengan substitusi inulin umbi gembili 2\%, 3\%, dan 4\%. Selain itu, perlakuan es krim dengan substitusi inulin umbi gembili $4 \%$ juga memiliki perbedaan bermakna terhadap es krim substitusi inulin umbi gembili $2 \%$ dan $3 \%$.

\section{PEMBAHASAN}

\section{Ekstraksi Inulin Umbi Gembili (Dioscorea esculenta)}

Umbi gembili menurut penelitian sebelumnya merupakan umbi yang memiliki kandungan inulin tertinggi yaitu sebesar $14,629 \%$ (bk). ${ }^{14}$ Pada penelitian ini ekstraksi umbi gembili menghasilkan inulin sebesar 10,92\% (bk). Hasil ekstraksi inulin yang lebih rendah mungkin disebabkan karena umbi gembili yang digunakan pada penelitian ini baru berusia sekitar 5-8 bulan. Umur panen umbi gembili di pasaran seharusnya berkisar 8-9 bulan. Lama umur panen berkaitan dengan kandungan air yang semakin menurun, sedangkan kandungan karbohidrat (pati dan serat) akan semakin meningkat. ${ }^{20}$ Diketahui kadar air umbi gembili yaitu $84,40 \% .^{14}$

Ekstraksi inulin umbi gembili pada penelitian ini menggunakan prinsip pelarutan inulin dalam air pada suhu tinggi dan pengendapan dengan etanol. ${ }^{15}$ Inulin mudah larut dalam air panas. Pada penelitian ini pemanasan dilakukan pada suhu $80-90^{\circ} \mathrm{C}$ selama 30 menit untuk mempertinggi kelarutan inulin dalam air. Ekstraksi dengan etanol diketahui akan menghasilkan lebih banyak jenis oligosakarida dibandingkan dengan ekstraksi air mendidih. ${ }^{21}$ Semakin panjang rantai gula akan lebih mudah larut dalam pelarut etanol, hal ini disebabkan etanol berifat kurang polar dibanding air. Ekstraksi menggunakan etanol $90 \%$ merupakan konsentrasi yang terbaik, yaitu dengan ratio umbi : etanol $=1: 3.22$

\section{Kadar Serat Es Krim dengan Substitusi Inulin Umbi Gembili}

Istilah serat makanan (dietary fibre) berbeda dengan serat kasar (crude fibre). Serat makanan (dietary fibre) adalah semua jenis serat yang tetap berada di kolon setelah melalui proses pencernaan, baik serat yang larut dalam air (soluble dietary fibre) maupun tidak larut dalam air (unsoluble dietary fibre). Serat kasar (Crude fibre) adalah serat tumbuhan yang tidak larut dalam air. 
Kadar serat pada es krim dengan substitusi inulin umbi gembili mengalami peningkatan dibandingkan dengan es krim kontrol. Nilai rerata serat terendah terdapat pada es krim kontrol atau tanpa substitusi inulin umbi gembili, sedangkan kadar serat tertinggi terdapat pada es krim dengan substitusi inulin umbi gembili $4 \%$. Berdasarkan analisis statistik, es krim dengan substitusi inulin umbi gembili memiliki pengaruh yang signifikan terhadap peningkatan kadar serat es krim.

Inulin merupakan polisakarida, termasuk karbohidrat yang disebut fruktan dan merupakan polimer yang mengandung gugus fruktosa dengan ikatan $\beta-2-1$ fruktofuransida. Inulin merupakan bentuk serat yang dapat dilarutkan, tidak dapat dicerna oleh enzim-enzim pencernaan karena enzim-enzim tersebut spesifik menghidrolisis ikatan $\alpha$ tetapi tidak mampu menghidrolisi ikatan $\beta$ pada inulin sehingga saat mencapai usus besar inulin tidak mengalami perubahan struktur. ${ }^{23}$ Inulin akan terfermentasi akibat aktivitas mikroflora yaitu bifidobakterium yang terdapat di usus besar sehingga inulin bersifat prebiotik. ${ }^{11}$

Penambahan CMC (Carboxy Methyl Cellulose) sebagai bahan penstabil menyebabkan es krim kontrol mengandung serat. CMC yang ditambahkan pada penelitian ini sebanyak 0,2 gram untuk 100 gram adonan es krim. CMC merupakan turunan selulosa, hasil reaksi antara selulosa yang bersifat alkali dengan asam kloroasetat. ${ }^{24}$ Selulosa merupakan salah satu serat polisakarida termasuk komponen dari dinding sel tanaman yang disusun oleh unit-unit D-glikopiranosa melalui ikatan $\beta$ (14)-glikosida. Selulosa merupakan serat tidak larut air sehingga tidak dapat dicerna oleh enzim pencernaan tetapi akan difermentasi oleh bakteri anaerob di dalam usus besar. Prevalensi kanker kolon sering dikaitkan dengan konsumsi selulosa sebab di kolon selulosa dapat memperpendek waktu transit bolus dan meningkatkan pembentukan feses, sehingga waktu kontak bahan karsinogen dengan mukosa kolon dapat menurun. ${ }^{25}$

\section{Kadar Lemak Es Krim dengan Substiusi Inulin Umbi Gembili}

Lemak merupakan sumber asam lemak esensial, seperti asam linoleat, linolenat, dan arakidonat yang dapat mencegah penyempitan pembuluh darah akibat penumpukan kolesterol. Lemak juga merupakan alat pengangkut dan pelarut bagi vitamin A, D, E dan K. Konsumsi lemak yang berlebih diketahui dapat berdampak buruk bagi kesehatan, seperti aterosklerosis, penyakit jantung koroner, dan obesitas. ${ }^{26}$ Penggunaan lemak dalam bahan makanan selain untuk menambah kalori, juga untuk memperbaiki tekstur dan cita rasa. Komponen lemak memberikan karakter fisik pada produk seperti aroma, tekstur, rasa, dan penampilan. Karakteristik fisik produk menjadi hilang ketika lemak dalam makanan tersebut dikurangi atau dihilangkan.

Kadar lemak es krim dengan substitusi inulin umbi gembili mengalami penurunan bila dibandingkan dengan es krim kontrol. Nilai rerata yang terendah adalah es krim dengan substitusi inulin umbi gembili $4 \%$, sedangkan kadar lemak paling tinggi adalah pada es krim kontrol atau tanpa substitusi inulin umbi gembili. Substitusi merupakan penggantian sebagian bahan utama dengan bahan lain dengan tujuan tertentu. Berdasarkan analisis statistik, es krim dengan substitusi inulin umbi gembili memiliki pengaruh yang signifikan terhadap penurunanan kadar lemak es krim. Hal ini disebabkan karena sumber lemak berupa whip cream sebesar $12 \%$ pada es krim digantikan sebagian dengan inulin umbi gembili sebesar 2\%-4\% sehingga secara langsung menyebabkan kadar lemak es krim turun.

Inulin diketahui dapat membantu memetabolisme lemak sehingga mempengaruhi penurunan kolesterol dan trigliserida. Inulin dapat mempengaruhi peningkatan ekskresi asam empedu melalui feses sehingga terjadi peningkatan pemanfaatan kolesterol yang mengakibatkan berkurangnya konsentrasi kolesterol di hati. Selain itu, inulin yang terdegradasi oleh bakteri menjadi asam lemak rantai pendek seperti propionat diketahui dapat menurunkan sintesis kolesterol dengan cara menghambat enzim hydroxymethylglutaryl-CoA reduktase. Inulin diketahui dapat mempengaruhi penurunan sekresi VLDL (very low density lipoprotein) yaitu melalui penurunan aktivitas enzim lipogenik sehingga mengakibatkan trigliserida ikut menurun. ${ }^{13}$

\section{Sifat Fisik Es Krim dengan Substitusi Inulin Umbi Gembili}

Melting rate adalah waktu yang dibutuhkan es krim sampai meleleh dengan sempurna yang dinyatakan dalam gram/menit. Es krim yang berkualitas saat dihidangkan pada suhu kamar tidak cepat meleleh, tetapi cepat meleleh pada suhu rongga mulut manusia atau suhu tubuh. Standar nilai melting rate pada penelitian ini berdasarkan nilai melting rate es krim komersial "wall's populaire" yaitu sebesar $1,41 \mathrm{ml} /$ menit. Es krim kontrol dan es krim yang disubstitusi dengan inulin umbi gembili bila dibandingkan standar memiliki nilai melting rate yang rendah. 
Nilai melting rate yang rendah menunjukkan bahwa es krim pada penelitian ini lebih tahan terhadap pelelehan. Semakin tinggi konsentrasi substitusi inulin gembili, nilai melting rate es krim semakin rendah. Hal ini disebabkan karena inulin memiliki gugus hidroksil yang berperan dalam penyerapan air. Kemampuan inulin menyerap air berkaitan dengan kemampuannya membentuk gel, semakin tinggi molekul air yang terperangkap dalam struktur gel maka viskositasnya semakin tinggi. ${ }^{27}$ Semakin tinggi viskositasnya menyebabkan nilai melting rate semakin rendah. Kecepatan pelelehan juga berkaitan dengan tinggi rendahnya overrun. Semakin tinggi overrun maka semakin cepat es krim tersebut meleleh, begitu sebaliknya semakin rendah overrun maka semakin lambat es krim tersebut meleleh.

Overrun adalah pengembangan volume es krim yang dihitung berdasarkan perbedaan volume produk dengan volume adonan mula-mula pada berat yang sama. Tidak terbentuknnya overrun mengakibatkan es krim berbentuk gumpalan yang keras, sedangkan es krim dengan overrun yang terlalu tinggi akan cepat meleleh. Standar nilai overrun es krim yang baik untuk skala industri 70 - $80 \%$, sedangkan untuk skala rumah tangga berkisar $35-50 \% .^{28}$

Overrun es krim kontrol pada penelitian ini termasuk pada standar overrun skala rumah tangga yaitu $36,83 \%$. Sedangkan es krim yang disubstitusi dengan inulin umbi gembili memiliki overrun yang rendah yaitu 27,33-33,78\%. Semakin tinggi konsentrasi substitusi inulin umbi gembili yang diberikan menyebabkan semakin banyak gugus hidroksil yang mengikat air sehingga dapat mempengaruhi nilai overrun. Selain itu, overrun yang rendah juga disebabkan karena tidak didukung oleh penginjeksian udara pada adonan saat proses pembekuan (freezing) seperti pada pembuatan es krim untuk skala industri besar. ${ }^{29}$

\section{Tingkat Penerimaan Es Krim dengan Substiusi Inulin Umbi Gembili}

\section{a. Warna}

Warna menentukan penampilan makanan dan merupakan rangsangan pertama pada indera mata yang dapat meningkatkan cita rasa. Berbeda dengan warna es krim kontrol, warna es krim dengan substitusi inulin umbi gembili memiliki warna yang bervariasi sesuai dengan konsentrasi inulin yang ditambahkan. Sesuai dengan karakteristik lemak susu, es krim kontrol pada penelitian ini berwarna putih cream atau putih susu, sedangkan es krim dengan substitusi inulin umbi gembili memiliki warna kuning sampai kuning kecoklatan.

Pengupasan umbi gembili dan pengeringan yang dilakukan saat ekstraksi menyebabkan inulin umbi gembili yang dihasilkan berwarna kuning kecoklatan. Umbi gembili yang dikupas mengalami reaksi pencoklatan (browning) enzimatik, hal ini disebabkan karena aktivitas oksidase seperti fenolase atau polifenolase yang akan mengkatalis reaksi oksidasi senyawa fenol menjadi quinon. Pengeringan akan menyebabkan reaksi browning non enzimatis, yaitu reaksi maillard antara gula pereduksi dengan asam amino pada bahan makanan yang mengalami proses pemanasan. $^{30}$

\section{b. Rasa}

Rasa merupakan salah satu faktor yang penting dalam menentukan cita rasa makanan. Terdapat 4 macam penilaian rasa makanan yaitu asin, manis, pahit, dan asam. Rasa dipengaruhi oleh beberapa faktor yaitu senyawa kimia, suhu, konsentrasi dan interaksi dengan komponen rasa yang lain. Presentase penambahan gula pada es krim sebesar $15 \%$, sedangkan presentase substitusi inulin sebesar 2\%-4\%. Inulin diketahui dapat digunakan sebagai pengganti gula. Inulin tidak menyebabkan karies gigi dan tidak memiliki after taste. $^{31}$

Hasil analisis tingkat penerimaan panelis terhadap parameter rasa menunjukkan bahwa tingkat penerimaan terendah yang masih dapat diterima adalah es krim dengan substitusi inulin umbi gembili $4 \%$ dan termasuk dalam kategori netral. Es krim dengan substitusi inulin umbi gembili $4 \%$ memiliki rasa yang lebih manis dibandingkan perlakuan lain. Hal ini disebabkan karena tingkat kemanisan inulin $10 \%$ dari kemanisan sukrosa. Kandungan gula inulin terdiri dari $90,81 \%$ fruktosa dan $4,71 \%$ glukosa. ${ }^{31}$

\section{c. Tekstur}

Kualitas es krim yang baik tidak hanya dinilai dari cita rasanya yang enak, tetapi juga dinilai dari segi tekstur. Tekstur yang lembut dan tegas merupakan fokus utama saat es krim di dalam mulut. ${ }^{32}$ Pembentukan kristal es yang besar dan tekstur yang lebih kasar terjadi karena kandungan lemak susu yang ada pada es krim terlalu rendah. Penggunaan CMC sebagai bahan penstabil dapat memperbaiki tekstur es krim karena bisa mengikat air dan mengurangi pembentukan kristal es.

Perlakuan es krim kontrol memiliki tekstur yang lebih creamy dan lembut dibanding es krim dengan substitusi umbi gembili. Es krim dengan 
substitusi inulin umbi gembili memiliki tekstur yang lebih padat. Semakin tinggi konsentrasi substitusi inulin gembili, tekstur es krim semakin padat. Inulin memiliki gugus hidroksil yang berperan dalam penyerapan air. Kemampuan inulin menyerap air berkaitan dengan kemampuannya membentuk gel, semakin tinggi molekul air yang terperangkap dalam struktur gel menyebabkan viskositasnya semakin tinggi. Semakin tinggi viskositasnya maka tingkat kekentalannya semakin tinggi. ${ }^{27}$ Es krim dengan substitusi inulin umbi gembili $2 \%$ memiliki tekstur yang dapat diterima dengan kategori suka.

\section{d. Aroma}

Aroma makanan merupakan daya tarik yang sangat kuat dan mampu merangsang indera penciuman sehingga dapat membangkitkan selera makan. Timbulnya aroma makanan disebabkan oleh terbentuknya senyawa yang mudah menguap. Dua atau lebih bau dapat bercampur untuk saling menguatkan atau saling menutupi. Aroma es krim sedikit tercium disebabkan karena es krim merupakan makanan beku sehingga zat yang berada di dalam es krim tidak menguap. ${ }^{32}$

Es krim kontrol tanpa substitusi inulin umbi gembili memiliki aroma alami lemak susu yang berasal dari bahan baku es krim itu sendiri. Es krim dengan substitusi inulin umbi gembili memiliki aroma yang berbeda dengan es krim kontrol. Reaksi maillard yang terjadi pada inulin umbi gembili menghasilkan aroma yang khas pada es krim perlakuan. Hal ini mengakibatkan penurunan tingkat penerimaan aroma es krim dengan substitusi inulin umbi gembili. Pembentukan aroma terjadi karena reaksi penguraian strecker asam $\alpha$-amino. Asam $\alpha$-amino bereaksi dengan senyawa dikarbonil yang terbentuk. Asam amino kemudian diubah menjadi aldehida dengan atom karbon yang berkurang satu. $^{33}$

Es krim yang direkomendasikan berdasarkan hasil penelitian ini adalah es krim dengan substitusi inulin umbi gembili $2 \%$. Es krim dengan substitusi inulin umbi gembili $2 \%$ memiliki skor tingkat penerimaan meliputi warna, aroma, tekstur, dan rasa yang paling baik dibandingkan es krim dengan substitusi inulin umbi gembili yang lain (inulin 3\% dan 4\%). Selain itu, es krim dengan substitusi inulin umbi gembili $2 \%$ lebih tahan terhadap pelelehan dibanding es krim komersial yang ada dipasaran serta memiliki nilai overrun yang mendekati nilai standar overrun skala rumah tangga. Es krim dengan substitusi inulin umbi gembili $2 \%$ memiliki kadar serat yang lebih tinggi dan kadar lemak yang lebih rendah dibandingkan dengan es krim kontrol.

\section{SIMPULAN}

1. Kadar serat paling tinggi dan kadar lemak paling rendah adalah es krim dengan substitusi inulin umbi gembili $4 \%$. Substitusi inulin umbi gembili berpengaruh terhadap peningkatan kadar serat dan penurunan kadar lemak es krim.

2. Es krim dengan substitusi inulin umbi gembili $4 \%$ paling tahan terhadap pelelehan. Es krim dengan substitusi inulin umbi gembili memiliki overrun yang rendah dan belum sesuai standar overrun skala rumah tangga.

3. Substitusi inulin umbi gembili berpengaruh terhadap penurunan tingkat penerimaan es krim.

\section{SARAN}

1. Es krim yang direkomendasikan berdasarkan hasil penelitian ini adalah es krim dengan substitusi inulin umbi gembili $2 \%$.

2. Sifat fisik (overrun) es krim dapat diperbaiki salah satunya dengan menggunaan alat ice cream maker yang dilengkapi dengan sistem pompa udara sehingga dimungkinkan nilai overrun es krim yang dihasilkan dapat sesuai dengan standar overrun skala industri.

\section{DAFTAR PUSTAKA}

1. Löndahl, Charlotte. Obesity - a threat to public health?. The Swedish Council for Working Life and Social Research (FAS); 2007.

2. Dehghan, M., Danesh A.N., dan Merchant A.T. Childhood obesity, prevalence and prevention. Nutrition Journal; 2005; 4:24

3. Abdullah, A., Wolfe R., Stoelwinder J.U., Courten, M.D., Stevenson C., Walls H.L., dan Peeters A. The number of years lived with obesity and the risk of all cause and cause specific mortality. International Journal of Epidemiology; 2011:40:985-996.

4. Finkelstein E.A., Khavjou O.A., Thompson H., Trogdon J.G., Pan L., Sherry B., Dietz W. Obesity and Severe Obesity Forecasts Through 2030. American Journal of Preventive Medicine; 2012.

5. Riset Kesehatan Dasar (RisKesDas) Tahun 2010. Badan Penelitian dan Pengembangan Kesehatan Kementrian Kesehatan RI; 2010.

6. Abdullah, M., Rehman S., Zubair H., Saeed H.M., Kousar S., dan Shahid M. Effect of Skim Milk in 
Soymilk Blend on the Quality of Ice Cream. Pakistan Journal of Nutrition; 2003; 2(5): 305-311.

7. Persatuan Ahli Gizi Indonesia. Tabel Komposisi Pangan Indonesia. Jakarta : PT Elez Media Komputindo; 2009.

8. Yavuz T. dan Ahmet S.U. Turkish consumers' purchase attitude and behaviours towards Kahramanmaras type ice cream as a local branded product. African Journal of Business Management. 2012; Vol. 6(34), pp. 9695-9703.

9. Tárrega A., Torres J.D., Costell E. Influence of the chain-length distribution of inulin on the rheology and microstructure of prebiotic dairy desserts. Journal of Food Engineering. Elsevier; 2011; 356363.

10. Guven M.,Yasar K., Karaca O.B., dan Hayaloglu A.A. The effect of inulin as a fat replacer on the quality of set-type low-fat yogurt manufacture. International Journal of Dairy Technology; 2005; Vol 58(3).

11. Pandiyan, C., Annal V.R., Kumaresan G., Murugan B., dan Rajarajan G. Effect of incorporation of inulin on the survivability of Lactobacillus acidophilus in synbiotic ice cream. International Food Research Journal; 2012; 19(4): 1729-1732.

12. Franck A., De Leenher L., and Belgium. Inulin in Polysaccharides and Polyamides in the Food Industry. Steinbuchel A, Rhee SK (ed). WileyVCH; 2005.

13. Kaur, N. and Gupta A.K. Applications of Inulin and Oligofructose in Health and Nutrition. J. Biosci.; 2002; 27: 703-714.

14. Yuniar, D.P. Karakteristik Beberapa Umbi Uwi (Dioscorea spp.) dan Kajian Potensi Kadar Inulinnya. [Skripsi]. Fakultas Teknologi Industri. Surabaya: Universitas Pembangunan Nasional "Veteran". 2010.

15. Widowati, S., Santosa, B.A.S., Sunarti, T.C., and Zaharani, A. Characterization of Inulin from Some Dahlia (Dahlia pinnata) Tuber. In Proceeding of The 9th ASEAN Food Conference. Jakarta : LIPI Press; 2005; Pp 1606-1621.

16. Badan Standarisasi Nasional. Cara Uji Makanan dan Minuman. Standar Nasional Indonesia (SNI): 01-2891-1992. 1992.

17. Apriyantono, A., Dedi F., Ni Luh P., Sedarnawati, Slamet B. Analisis Pangan. Bogor: Departemen Pendidikan dan Kebudayaan Direktorat Jenderal Pendidikan Tinggi Pusat Antar Universitas Pangan dan Gizi IPB. 1989.

18. Soukoulis, C., Chandrinos, I. dan Tzia, C. Study of the Funcionality of Selected Hidrocolloids and Their Blends with K-carrageenan on Storage Quality of Vanilla Ice Cream. LWT-Food Science and Technology; 2008; 41: 1816-1837.

19. Marshall R.T dan Arbuckle W.S. Ice Cream. Chapman and Hall. New York; 2000.

20. Sarungallo Zita L. dan Budi Santoso. Sifat Fisik Dan Komposisi Kimia Buah Aibon (Brugueira
Gymnorhiza L.) Pada Berbagai Tingkat Kematangan. Jurnal Bionatura; 2007; 9: 83 - 92.

21. Marlis, A. Isolasi Oligosakarida Ubi Jalar (Ipomoea batatas L.) dan Pengaruh Pengolahan terhadap Potensi Prebiotiknya. [Tesis]. Bogor : Institut Pertanian Bogor. 2008.

22. Budiwati, Thelma A. Pengembangan Proses Pembuatan Inulin Dari Umbi Tanaman Dahlia. Pusat Penelitian Kimia LIPI. 2010.

23. Gropper, S. S., Smith, J. L., Groff, J. L. Advanced Nutrition and Human Metabolism. Fifth Edition. Wadsworth: Cengage Learning. 2009.

24. Glicksman, M. Food Hydrocoloids. Florida: CRC Press, Ibc; 2000; 1: p.199.

25. Coleman, Leana J. A Diet Containing $\alpha$-Cellulose and Fish Oil Reduces Aberrant Crypt Foci Formation and Modulation Other Possible Marker For Colon Cancer Risk in Azoxymethane-Treated Rats. Nutrition and Cancer Journal; 2002; 132: 2312-18.

26. Akoh, C.C. and Min, D.B. Food Lipids Chemistry, Nutrition, and Biotechnology. New York: Marcel Dekker, Inc. 2002.

27. Barclay, T., Markovic M. G., Cooper, P., Petrovsky, N. Inulin - a versatile polysaccharide with multiple pharmaceutical and food chemical uses. Journal of Excipients and Food Chemicals; 2010: 1(3).

28. Susilorini, T. E. dan Sawitri, M. E. Produk Olahan Susu. Jakarta: Penebar Swadaya; 2006.

29. Masykuri, Y. B. dan Pramono, D. Ardilia. Resistensi Pelelehan, Over-Run, dan Tingkat Kesukaan Es Krim Vanilla yang Terbuat dari Bahan Utama Kombinasi Krim Susu dan Santan Kelapa. Jurnal Aplikasi Teknologi Pangan; 2012: Vol.1(3).

30. Peter SM. Understanding Food Nutrition and technology. United Stated of America: Thomson Learning; 2003; p.120-148.

31. Kaur, N. dan Gupta, A. Applications of Inulin and Oligofructose in Health and Nutrition. Journal of Biosciences; 2002; 27; 703-714.

32. Clark S., Costello M., Drake M., and Bodyfelt F. The Sensory Evaluation of Diary Product, 2nd ed. New York: Springer; 2009; p.271-332.

33. Deman, J.M. Kimia Makanan. Bandung : Institut Teknologi Bandung. 1997. 